\title{
Hanford Mission Plan Risk-Based Prioritization Methodologies
}

\author{
W. A. Hesser \\ J. L. Butcher ${ }^{(a)}$ \\ M. S. Madden \\ N. M. Pyron
}

August 1994

Prepared for

the U.S. Department of Energy

under Contract DE-AC06-76RLO 1830

Pacific Northwest Laboratory

Richland, Washington 99352

(a) Westinghouse Hanford Company
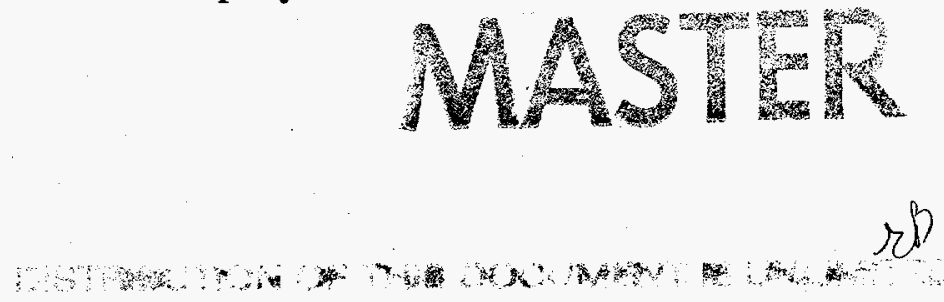



\section{DISCLAIMER}

This report was prepared as an account of work sponsored by an agency of the United States Government. Neither the United States Government nor any agency thereof, nor any of their employees, make any warranty, express or implied, or assumes any legal liability or responsibility for the accuracy, completeness, or usefulness of any information, apparatus, product, or process disclosed, or represents that its use would not infringe privately owned rights. Reference herein to any specific commercial product, process, or service by trade name, trademark, manufacturer, or otherwise does not necessarily constitute or imply its endorsement, recommendation, or favoring by the United States Government or any agency thereof. The views and opinions of authors expressed herein do not necessarily state or reflect those of the United States Government or any agency thereof. 


\section{DISCLAIMER}

Portions of this document may be illegible in electronic image products. Images are produced from the best available original document. 


\section{Executive Summary}

Sites across the U.S. Department (DOE) complex recognize the critical need for a systematic method for prioritizing among their work scope activities. Here at the Hanford Site, Pacific Northwest Laboratory and Westinghouse Hanford Company (WHC) conducted preliminary research into techniques to meet this need and assist managers in making financial resource allocation decisions. This research is a subtask of the risk management task of the Hanford Mission Plan as described in the WHC Integrated Planning Work Breakdown Structure 1.8.2 Fiscal Year 1994 Work Plan.

The research team investigated prioritization techniques used at other DOE sites and compared them with the Priority Planning Grid (PPG), a tool used at Hanford. We concluded that the PPG could be used for prioritization of resource allocation, but it needed to be revised to better reflect the Site's priorities and objectives. The revised PPG was tested with three Hanford programs, the PPG was modified, and updated procedures were prepared.

We recommend that the WHC Program Integration Team (PIT) be briefed on the revised PPG and be taught how to use it. In addition, we recommend that the PIT should apply the PPG as a first step in prioritizing FY 1995 work scope activities. Finally, we recommend that DOE Richland Operations Office be briefed on the PPG to secure their blessing to use the tool across the Hanford Site. 



\section{Contents}

Executive Summary $\ldots \ldots \ldots \ldots \ldots \ldots \ldots \ldots \ldots \ldots \ldots \ldots \ldots$

1.0 Introduction $\ldots \ldots \ldots \ldots \ldots \ldots \ldots \ldots \ldots \ldots \ldots \ldots \ldots \ldots \ldots \ldots$

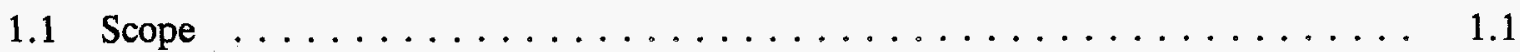

1.2 DOE-HQ Guidance $\ldots \ldots \ldots \ldots \ldots \ldots \ldots \ldots \ldots \ldots \ldots \ldots$

1.3 General Approach $\ldots \ldots \ldots \ldots \ldots \ldots \ldots \ldots \ldots \ldots \ldots \ldots$

2.0 Prioritization Methods $\ldots \ldots \ldots \ldots \ldots \ldots \ldots \ldots \ldots \ldots \ldots \ldots \ldots \ldots \ldots$

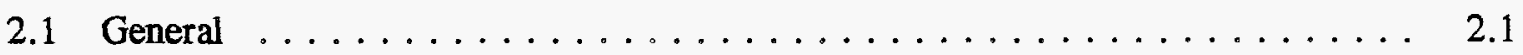

2.2 Characteristics of Prioritization Methods $\ldots \ldots \ldots \ldots \ldots \ldots \ldots \ldots \ldots \ldots$

2.3 The Applicability and Issues of Prioritization Methods $\ldots \ldots \ldots \ldots \ldots \ldots$

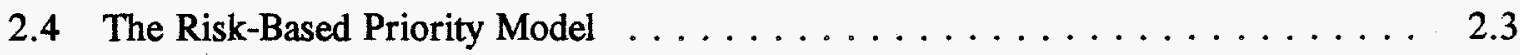

2.5 The Laboratory Integration Prioritization System $\ldots \ldots \ldots \ldots \ldots \ldots \ldots$

2.6 The Original Priority Planning Grid $\ldots \ldots \ldots \ldots \ldots \ldots \ldots$

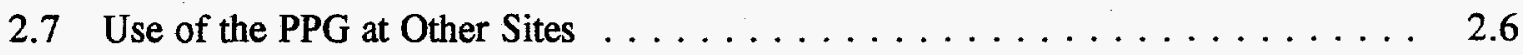

3.0 Resource Allocation and Prioritization at Hanford $\ldots \ldots \ldots \ldots \ldots \ldots$

3.1 Current Prioritization System $\ldots \ldots \ldots \ldots \ldots \ldots \ldots \ldots \ldots \ldots \ldots \ldots$

3.1.1 DOE Richland Operations Office Guidance $\ldots \ldots \ldots \ldots \ldots \ldots . . \ldots$

3.1 .2 Current Prioritization Process $\ldots \ldots \ldots \ldots \ldots \ldots \ldots \ldots \ldots \ldots \ldots$

3.1.3 Shortcomings with the Current System $\ldots \ldots \ldots \ldots \ldots \ldots . \ldots \ldots$

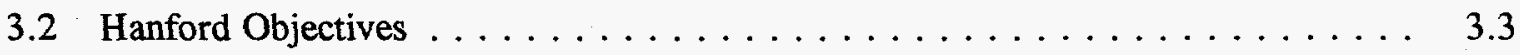

3.3 Modification of the Priority Planning Grid $\ldots \ldots \ldots \ldots \ldots \ldots$

3.4 Tests of the Priority Planning Grid $\ldots \ldots \ldots \ldots \ldots \ldots \ldots$

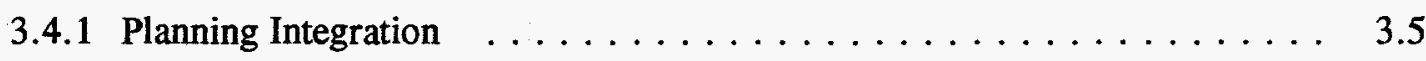


3.4 .2 Analytical Services . . . . . . . . . . . . . . 3.6

3.4 .3 Facility Operations $\ldots \ldots \ldots \ldots \ldots \ldots \ldots \ldots \ldots \ldots$

3.5 Lessons Learned $\ldots \ldots \ldots \ldots \ldots \ldots \ldots \ldots \ldots \ldots \ldots \ldots$

4.0 Prioritization Methodology Issues $\ldots \ldots \ldots \ldots \ldots \ldots \ldots \ldots \ldots \ldots$

4.1 Compliance $\ldots \ldots \ldots \ldots \ldots \ldots \ldots \ldots \ldots \ldots \ldots \ldots \ldots \ldots \ldots$

4.2 Management Activities $\ldots \ldots \ldots \ldots \ldots \ldots \ldots \ldots \ldots \ldots \ldots \ldots \ldots$

4.3 Support and Infrastructure Activities $\ldots \ldots \ldots \ldots \ldots \ldots \ldots \ldots \ldots$

4.4 Multi-Year Activities $\ldots \ldots \ldots \ldots \ldots \ldots \ldots \ldots \ldots \ldots \ldots \ldots$

4.5 Critical Path Activities $\ldots \ldots \ldots \ldots \ldots \ldots \ldots \ldots \ldots \ldots \ldots$

4.6 Non-Discretionary Activities $\ldots \ldots \ldots \ldots \ldots \ldots \ldots \ldots \ldots \ldots \ldots \ldots \ldots$

4.7 Funded Versus Not-Funded Building Blocks $\ldots \ldots \ldots \ldots \ldots \ldots \ldots \ldots$

4.8 Building Block Size $\ldots \ldots \ldots \ldots \ldots \ldots \ldots \ldots \ldots \ldots \ldots \ldots$

4.9 Benefit-Cost Analysis $\ldots \ldots \ldots \ldots \ldots \ldots \ldots \ldots \ldots \ldots \ldots$

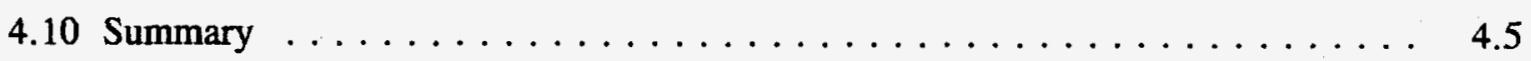

5.0 Conclusions and Recommendations $\ldots \ldots \ldots \ldots \ldots \ldots \ldots \ldots \ldots \ldots \ldots \ldots$

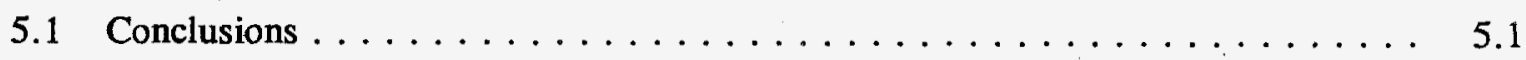

5.2 Recommendations $\ldots \ldots \ldots \ldots \ldots \ldots \ldots \ldots \ldots \ldots \ldots \ldots \ldots \ldots$

Appendix A - Priority Planning Grid Use Procedure $\ldots \ldots \ldots \ldots \ldots \ldots \ldots \ldots$

Appendix B - Modified Priority Planning Grid $\ldots \ldots \ldots \ldots \ldots \ldots \ldots \ldots$

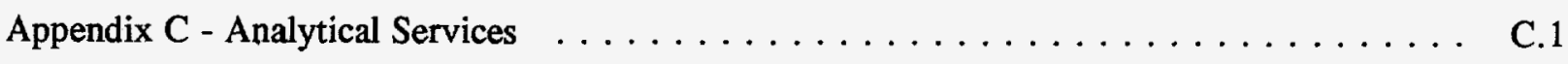

Appendix D - Facility Operations . . . . . . . . . . . . . . . . 


\subsection{Introduction}

The purpose of this document is to describe preliminary research into techniques for prioritizing among work scope activities at the Hanford Site and to assist managers in making financial resource allocation decisions. The research was conducted by Pacific Northwest Laboratory (PNL) and Westinghouse Hanford Company (WHC) personnel as a subtask of the risk management task of the Hanford Mission Plan (HMP). It is described in the WHC Integrated Planning Work Breakdown Structure (WBS) 1.8.2 Fiscal Year (FY) 1994 Work Plan. Milestone Description Sheet PSS-94-024 refers.

\subsection{Scope}

The overall purposes of risk management are to introduce a systematic approach to decision making when risk is a significant factor, taking steps to reduce those risks, and monitoring the results of those decisions. A principal decision facing Hanford managers is the allocation of fiscal resources to pay for program activities. This report describes some of the most important prioritization techniques used at other U.S. Department of Energy (DOE) sites and compares them with the Priority Planning Grid (PPG), a tool used at Hanford. The current system of resource allocation at Hanford is described, followed by a description of the modifications made to the PPG and the results of recent tests of that Grid. Finally, conclusions and recommendations are presented.

\subsection{DOE-HQ Guidance}

The new administration has, on several occasions, indicated that improved management practices are required. Specifically, Assistant Energy Secretary Grumbly has directed DOE managers to "get the system under control managerially and financially." Moreover, he has indicated that it will be DOE policy to allocate resources to those activities which offer the greatest reduction in risk to the public, workers, and the environment. The DOE Headquarters (HQ) has directed field offices to be more outcome oriented and to improve the decision-making process.

This emphasis on better decisions, risk-based resource allocation, and reinvention of government mandates that Hanford implement practices to improve its decision making. This task is designed to help achieve that mandate.

\subsection{General Approach}

The general approach for this research consisted of four parts. First, we determined how priorities were established and how resources are currently allocated at Hanford. Then, we began an 
examination of different techniques used (or are at least available) at other DOE organizations. While examining these other tools, we began a modification of the PPG, which was already in use at Hanford for selected purposes. We broadened the applicability of the PPG to include benefits, especially those related to Site objectives as stated in the HMP. Finally, we tested the PPG with three WHC programs to determine its suitability as a tool in resource allocation decisions. 


\subsection{Prioritization Methods}

This section describes the methods used in the DOE complex for the prioritization of activities and, often, for the allocation of resources based on that prioritization. The information described herein comes from DOE planners and analysts, especially those who belong to the Prioritization Methodology User's Group.

\subsection{General}

For many years it has been argued that government agencies and their prime contractors should take a more scientific approach to the way they set policy and allocate resources in support of the policies they set. Those who make this argument point to various theories for prescribing and rationalizing choices, and they maintain that societal goals could be achieved more cost effectively if these theories were applied. Recent government actions encourage, and in some cases, require government decisions to be evaluated. using formally defined principles of rationality and rigorous analytical approaches, such as regulatory impact analysis. The DOE in its Strategic Plan has identified the implementation of risk-based decision making as one of its highest priorities. This implies the use of a structured decision-making technique with risk reduction as the dominant evaluation criteria.

\subsection{Characteristics of Prioritization Methods}

In recent years, various disciplines have produced a considerable amount of literature and a number of methodologies and tools seeking solutions to the problem of allocating resources appropriately in support of the nation's environmental management activities. Despite the broad range of disciplines involved, most of these solutions are based on some type of structured, quantitative, prioritization procedure for evaluating technical or scientific information. Most of these techniques envision a system wherein all decisions are consistent, socially and politically acceptable, and scientifically defensible. Some of these methodologies include cost-benefit/risk-benefit analysis, risk analysis, multi-attribute utility analysis, and decision analysis. Many also share several other characteristics, including the following:

- They often implicitly assume that the input data are of equal quality across all relevant input variables.

- The procedures often are designed to be used by a single decision maker.

- They often lead to a clearly defined, optimal, uncontested, and permanent decision.

- They are often apolitical, with no reference to government structures and objectives. 
- They appear to ignore the way that difficult decisions are actually made.

- They tend to be normative rather than descriptive.

The DOE-HQ Strategic Plan has identified the implementation of risk-based decision making as one of its highest priorities. Currently, DOE and its contractors use a variety of risk-based prioritization approaches for different applications, including resource allocation. For the purposes of this analysis, four types of risk-based, quantitative prioritization approaches are considered: binning systems, quantitative aggregations of scores and weights, matrix approaches, and multi-attribute decision analysis.

In binning systems, different types of consequences which are determined to carry approximately similar weight are "binned" together and assigned a single weight. For example: a serious injury to a worker, a substantial fine as a result of noncompliance with regulations, and a major slip in the schedule of a critical path activity might all be "binned" together, and any of the items to be prioritized that related to these consequences would be put in that bin and all would receive the same weight.

Quantitative aggregation is a process in which the items to be prioritized are scored against a given set of criteria. Then, based on the scores, ranges are established and assigned relative values, such as "high", "medium", and "low".

In the matrix approach, the scoring criteria and the consequences are laid out on the axes of a matrix in ascending or descending order based on their importance or severity. An individual score for the item to be prioritized is derived by selecting a cell that represents the expected outcome with respect to each of the criteria and summing the scores for all of the criteria. Items are then ranked according to their scores.

Decision analytic approaches involve a combination of systems analysis and statistical decision theory. The problem is structured in terms of an objective or utility function. Preferences and probabilities for achieving the objectives are quantified and then aggregated for each of the items to be prioritized to indicate its overall impact on the achievement of the stated objectives. The items are then ranked accordingly.

These approaches are discussed briefly below in terms of how they treat the basic components of the risk equation: Probability of Occurrence $x$ Consequence of Occurrence $=$ Risk. That is, how they measure probability, how they combine probability and consequences, how they measure consequences, whether they include the population at risk, how they consider different types of risk, and how they prioritize budget items.

The binning, matrix, and decision-analysis approaches are similar in the way they treat probability. In these approaches, the probabilities are analyzed by aggregating (binning) or by continuous distribution functions. Quantitative aggregations are different in that they require more information about the probability distributions than is normally available. Furthermore, assumptions about the final form of the quantitative aggregation relative to the likelihood scale are required. 
Despite the similarities in the treatment of probabilities, greater differences occur in the way that the approaches combine the probabilities with the consequences. Binning and quantitative aggregation combine probabilities and consequences additively, which is not consistent with the standard equation for risk. The matrix and decision-analysis approaches use the multiplicative form necessary for the risk equation.

Consequences are treated as the impacts of an adverse event. Generally, the binning, matrix, and decision-analysis approaches are consistent in their handling of consequences, and there is a natural migration from bins to levels on the matrix axis to decision-analysis scales.

\subsection{The Applicability and Issues of Prioritization Methods}

In general, the selection of a prioritization method for a given problem is not a trivial task. There are no clear-cut rules for deciding how much analysis should be done or how sophisticated the tools should be. If anything, the rules of common sense should apply. Factors such as the amount of time and resources available for data collection and analysis, the logical soundness and completeness of the approach, the degree of accuracy or precision required, and the external/political realities of the situation (i.e., the practicality and acceptability of the approach) should be considered. Therefore, to identify the most useful prioritization approach, it is key that the analyst clearly understand the problem being addressed in terms of these factors.

The lack of a single, well-tested and universally appropriate method for analyzing a decision makes the selection of an approach the most significant issue facing the analyst today. The literature suggests that selection of an inappropriate approach to the problem being addressed is the most frequent cause of the failure of an analysis to produce a positive effect on the decision process. Analysts and decision makers must be extremely careful to ensure that the approach matches the needs of the situation.

Another of the most common issues discovered is the misconception held by many participants in a prioritization decision process that the analysis, the ranking, constitutes the decision. This misconception leads to reluctance and even resistance to the use of analytical techniques. It is key that all the participants in the process clearly understand the role of the analysis in the overall decision.

\subsection{The Risk-Based Priority Model (Oak Ridge)}

This model is a multi-attribute decision model that is used at the Oak Ridge National Laboratory to evaluate and relatively rank waste management projects based on the estimated risk reduction they will achieve. It considers the projects with respect to the following seven areas of impact:

- Public health and safety

- Environmental protection 
- Site personnel safety

- Regulatory compliance

- External confidence

- Mission and operational performance

- Business efficiency.

Each of the waste management projects that are evaluated with this methodology is viewed as an effort to reduce either the severity of a negative consequence or the likelihood that the consequence will occur. The methodology is constructed in the form of a matrix. Rows represent the severity of potential impacts, and columns represent the likelihood of occurrence. The seven areas of impact are weighted and the probabilities are aggregated into categories of "very high", "medium", and "low". The risk scores are derived by multiplying the severity of the impacts by the probability of occurrence.

The model can be used to evaluate the existing risks; that is, the severity of impacts that may occur and the probability of occurrence if a project is not implemented. Then, the estimated risk reduction is evaluated by comparing existing risks with the risks that will remain after the project is completed (computed in the same manner). The result is a net project benefit score, which is then used to prioritize the projects.

\subsection{The Laboratory Integration Prioritization System (Los Alamos)}

This system is a risk-based prioritization approach that was developed and used at the Los Alamos National Laboratory. Like the Oak Ridge model, its approach was derived from fundamental principles of decision analysis and uses multi-attribute utility theory to solve the prioritization problem. This approach quantifies uncertainty as probabilities and formally quantifies benefits using value functions.

The prioritization procedure defines risk as the possible occurrence of an undesirable impact in one or more of the following areas:

- Worker health and safety

- Public health and safety

- Environmental resources

- Issues relative to community concerns, socioeconomic impacts, business and economic development, or social infrastructure burdens 
- The level of regulatory compliance

- Laboratory programs and operations

- Laboratory efficiency and operation throughout.

A quantitative measure is developed for each category above, and each activity is evaluated using these measures. This is done by defining the averted risk as the baseline risk, plus the estimated risk reduction as a result of the activity. The benefit from averted risk is quantified into dollars consistent with management's value function as determined by formal elicitation procedures following welldefined preference theory theorems.

The result is a dollar value of risk-reduction benefit associated with an activity. This benefit is then compared with the benefits and costs of other activities to determine the most cost-effective investments.

\subsection{The Original Priority Planning Grid}

The PPG was developed in 1991 for use at the Hanford Site to rank projects by risk reduction (benefit) and by benefit-cost ratios (i.e., the relative risk reduced or the relative risk reduced per unit cost expended). Proposed program activities are evaluated and ranked based on their support of Sitewide goals and objectives. The rankings are then used by management as a first cut in funding allocation.

The PPG is made up of rows and columns. The rows consist of 10 categories which embody the goals and objectives of the Hanford Site. The columns represent consequence severity, for each category, which may result from an activity not being funded. Associated with each severity level is a point score, in which the most severe consequences receive the highest scores. The aspect of a multiattribute decision tool is built into the PPG by ordering the categories according to the priorities assigned by DOE. As one travels down the rows of categories, the maximum possible risk score decreases. In addition, the scores are an exponentially decreasing function; therefore, the maximum score that can be achieved in the last category is a small fraction of the maximum value for the first category.

When applying the PPG, four elements must be well defined for activities to be prioritized: 1) the objective function, 2) size (in dollars) of the activity planned to address the issue, 3) consequences which will occur if the activity is not funded, and 4) probabilities of each independent occurrence in all categories being evaluated. With specific scenarios in mind, each activity is evaluated in each category. For each category, consequences are chosen which might occur if the activity is not completed, a value is assigned to the consequence, then multiplied by its probability of occurrence. Activities may 
have independent consequences with different probabilities of occurrence in a single category, in which case, all values are used in the final score. The resulting scores are summed to yield the relative risk averted by funding the activity.

When establishing the size of activities to be evaluated, it is necessary to ensure each activity is large enough for its completion to represent a defined objective that has an associated reduced risk. In addition, to avoid confusion in application of the PPG, the activity should not include smaller portions which, when broken out, have varying associated risk levels. Although there will be exceptions, the guide rule for project size is $\$ 20 \mathrm{~K}$ to $\$ 200 \mathrm{~K}$. Projects that are relatively low cost, or those that fall under a programmatic budget, are generally not good candidates for the PPG.

\subsection{Use of the PPG at Other Sites}

Starting with the original PPG, then modifying it to fit their needs, many organizations throughout the complex have adopted the concept of the PPG. The uses range from prioritizing clean-up and refurbishment spending according to the relative risk averted by proposed activities to overall prioritization of a site's budget. The PPG is an easily adaptable tool that is well-known and generally accepted by the DOE sites as a viable risk-based, decision-making methodology in the process of prioritizing activities. 


\subsection{Resource Allocation and Prioritization at Hanford}

This chapter describes the current prioritization system, the missions and objectives of the Hanford Site, the modification of the PPG to incorporate those objectives, and the results of the tests of the PPG with three Hanford programs: Integrated Planning, Analytical Services, and Facility Operations.

\subsection{Current Prioritization System}

The current prioritization system has its basis in DOE Richland Operations Office (DOE-RL) guidance from 1992. This section describes that guidance and explains how it is used to prioritize among Hanford activities.

\subsubsection{DOE Richland Operations Office Guidance}

On January 16, 1992, the DOE-RL management provided WHC guidance on Hanford Site priorities. The priorities were to be used in resolving FY 1992 and FY 1993 funding issues in the development of the FY 1994 Five-Year Plan for the Waste Management Program. It specifically excluded the Environmental Restoration program. Without additional guidance for subsequent years, this guidance continues to be used today.

Part I of the guidance letter consisted of six major categories, with at least one subcategory listed under each major category. These provided general guidelines for the prioritization of various safety and compliance activities. Table 3.1 displays the categories/subcategories with prioritization level indicators A2, B1, D1, etc.

Part II of the letter discussed essential activities which were not amenable to prioritization against the priorities of Part I. WHC was to determine the level of service necessary in each to support the top priorities of Part I.

\subsubsection{Current Prioritization Process}

The prioritization process is initiated within the programs. Each program establishes its own priority list based on critical path schedules, stakeholder and regulator values, and other factors affecting the Hanford Site and that program. The next part of the process is initiated through the Program Integration Team (PIT), a team consisting of the program manager from each of the major programs. This part consists of each program manager listing his or her prioritized key program tasks, the priority level from the DOE guidance, and the cost. A summation of all program work items by priority level (e.g., all work scope with a B1 priority level) with associated costs is then prepared. The dollar value of this summarized list is then compared with the dollars available per funding guidance. To complete all work scope activities, there are usually more funds required than funds available, resulting in a list of "key unfunded" items, many of which are in high-priority categories. 
Table 3.1. 1992 DOE-RL Prioritization Guidance

\begin{tabular}{|c|c|c|}
\hline A. Safe Operations & A1 - Unresolved/imminent safety issues & $\begin{array}{l}\text { A2 - Maintain safe facility } \\
\text { configuration }\end{array}$ \\
\hline B. Compliance & B1 - Environmental laws and Tri-Party Agreement & B2 - Pursue corrective actions \\
\hline $\begin{array}{l}\text { C. Safety Assurance (not } \\
\text { covered above) }\end{array}$ & C1 - Enhance public safety & C2 - Enhance worker safety \\
\hline $\begin{array}{l}\text { D. Compliance Assurance } \\
\text { (not covered above) }\end{array}$ & $\begin{array}{l}\text { D1 - Prevent non-adherence to safety and } \\
\text { environmental DOE Order requirements }\end{array}$ & $\begin{array}{l}\text { D2 - Corrective actions to ensure } \\
\text { compliance with DOE } \\
\text { Orders }\end{array}$ \\
\hline E. Conduct of Operations & E1 - Pursue effective operations & \\
\hline F. Enhanced Operations & F1 - Pursue activities not required but desirable & \\
\hline
\end{tabular}

The next step is a review of work scope items in the key unfunded list to determine if the item has a higher priority than items in the same priority level on the funded list. For example: is the unfunded Priority B1 item in Program A really of less importance than a funded Priority B1 item in Program B, Program $\mathrm{C}$, etc. When going through this process, the program managers must make judgment calls on what is best for the Hanford Site mission. There is no tool available to assist them further in rating work scope in the same prioritization category/level.

After the PIT reaches a consensus, recommendations are made to the Program Executive Council. This group consists of WHC top management, who makes the final decisions on what work items will be recommended for funding in the fiscal years under discussion. Key unfunded items are reevaluated during the year as funding scenarios change.

\subsubsection{Shortcomings with the Current System}

The most significant problem with the current system is that the 1992 DOE-RL guidance does not provide sufficient information for choosing among program activities. Furthermore, that guidance does not adequately address the different objectives at Hanford. It is too focused on safety and compliance, to the exclusion of other Site objectives, e.g., expediting cleanup or increasing stakeholder confidence. While it may have reflected the thinking two or three years ago, it needs to be updated.

The current system of prioritizing activities is largely on consensus. That is, discussions continue until the PIT agrees with the recommended list. These discussions often favor program managers who can best argue the benefits of their particular program. It is generally difficult to reconstruct the process by which the final product is obtained. Certainly, there is no formal record of how choices were made and priorities established. Moreover, it is generally agreed that a different set of PIT managers would produce a different (and potentially much different) set of recommended work scope activities. 


\subsection{Hanford Objectives}

The Site mission has three components:

- Clean up the Site.

- Provide scientific and technological excellence to meet global needs.

- Partner in the economic diversification of the region.

Nine intermediate objectives, published in the HMP to enable us to accomplish those missions, are briefly repeated here:

1. Plan and conduct safe waste management, environmental restoration, and operational activities. Hanford will manage and eliminate the urgent risks and inherent threats that exist in our system. Specifically, the major safety risks posed by the high-level waste tanks and the risks associated with storage of spent nuclear fuel will be reduced. Our intent is to create a safe and healthy work place, one that is free from accidents, injuries, and adverse health effects. We will also create a safety culture that leads the DOE in safe operations, hazard recognition, communication, and mitigation.

2. Plan and conduct environmentally sound waste management, environmental restoration, and operational activities. Our waste management and environmental restoration activities, as well as our day-to-day operations, will continue to protect public health and will have minimal impact on the environment. We will ensure the Columbia River is protected and will establish a groundwater management strategy for the Site.

3. Comply with regulations and requirements. We will conduct activities in accordance with consistently interpreted and applicable regulations and approved, well-defined sets of requirements. We will comply with the spirit, as well as the letter, of applicable laws.

4. Plan and conduct cost-effective waste management, environmental restoration, and operational activities. Through the use of systems engineering principles, we will manage Hanford cleanup as an integrated project. We will establish and maintain a cost, schedule, and technical baseline that will increase public confidence that taxpayer dollars are being spent effectively. Programs are expected to reduce costs through increased productivity. We will significantly improve the decision-making process across the Site, implement expanded risk assessment and risk management activities, and ensure risk reduction is considered in all decisions.

5. Expedite environmental cleanup. Milestones as set forth in the Tri-Party Agreement will be met or exceeded, and, consistent with safety, practices that expedite cleanup and demonstrate progress will be implemented. Our intent is to achieve faster progress. 
6. Develop and maintain stakeholder confidence in what we do. A stronger partnership between the DOE and its stakeholders will be established. Managers will change the way they make decisions. Decision processes will be open and integrated to ensure they are not viewed as secretive and compartmentalized. Stakeholders will be provided meaningful opportunities to participate in resource allocation, land use, technology development, and other key decisions. Our intent is to achieve informed consent among our stakeholders and to build trust through openness and two-way communications. Everyone involved in Hanford operations and decisions will be part of the Hanford team. Information sharing and teamwork will be emphasized.

7. Provide strong support to economic transition. Hanford will partner in efforts to develop the local economy and to increase economic diversification, including privatization and technology transfer. Our intent is to ensure the economic health of the area after completion of the Site cleanup. Programs will include support for economic development in their plans.

8. Use science and technology for cleanup and national needs. We intend to build a world-class center of science and technology that has impact beyond Hanford. We will develop and use innovative science and technology that contribute to the National Energy Strategy and DOE objectives. We will set the standard in the DOE in directly linking science and technology efforts to specific cleanup projects. We will also continue to support the scientific education of our young people and will encourage interest in science, mathematics, and engineering through employment opportunities, Site visits, and mentoring of science education professionals.

9. Accomplish an effective workforce transition to the Site mission. Managers will ensure their workers are trained and motivated to accomplish the cleanup mission by establishing minimum qualifications for their personnel and training for them to function safely and proficiently. Those investments necessary to retain a high-quality, professional workforce will be made. Our intent is to match employee skills to the work activities and to empower employees to perform work effectively.

\subsection{Modification of the Priority Planning Grid}

Though well suited to scoring normal adverse impacts associated with environmental protection, safety, and health (ES\&H) risks, the original PPG lacked in the area of evaluating programmatic risks and in assessing the relative benefit of funding one activity versus another. To improve these areas, the PPG has been modified in several important ways.

To place the projects, especially those with no specific ES\&H risk reduction, in a benefit-oriented light, the new PPG ranks activities by asking the question, "What benefits will be achieved if this activity is funded?" For each category, the person scoring the activities (usually a manager) selects the benefit that represents the anticipated result of carrying out the activity. Consequence probabilities are no longer used since they are usually resource intensive and require considerable effort to calculate. 
Even then, they are oftentimes not accurate. In addition, the categories are tied directly to the Hanford Site mission and objectives, such as protecting the public and the environment, increasing stakeholder confidence, and demonstrating excellence in science and engineering.

Once scored, costs versus benefits for each activity are analyzed. Those activities which provide the highest return on investment are recommended as the first on the list for funding. After all activities have been prioritized, the list will be approved by the WHC program managers who are responsible for meeting the various requirements and mandates. Subject to agreement of all the managers, the final prioritization of the activities may be modified. The finalized list will be sent to DOE-RL and finally to DOE-HQ for ultimate approval.

Note that benefit-cost ratios should not be the only figure of merit. Some large, expensive programs may have a relatively low ratio, but, overall, they produce the greatest benefit to the Site (at least in terms of PPG scoring). The highest benefit return per dollar is ideal, but it is not always practical. See Section 4.9 for more discussion on this topic.

The primary advantage to the modifications made to the PPG is that all proposed activities can be scored and ranked in accordance with their impact on Site objectives. This provides managers with a defensible decision-making tool. It allows them to give priority to those activities which are both costeffective and can be shown to provide a definite contribution to the Site in achieving its mission and objectives. A secondary advantage comes from the ability to reconstruct prioritization decisions at a later date and to explain those decisions, if necessary.

The procedures for using the PPG and the modified PPG are attached as Appendices A and B, respectively.

\subsection{Tests of the Priority Planning Grid}

Testing the PPG was required to determine its ability to prioritize the diverse activities at Hanford. Three tests were conducted using the FY 1995 target case building blocks provided by the programs being tested. During the tests, both PNL and WHC personnel acted as trainers and moderators. The moderators assured unrealistic scores were not given to any work scope activities. The outcome of each test was evaluated to determine if modifications to the PPG were necessary, for lessons learned on its use, and if issues were raised which are beyond the control of the group developing the PPG. The results of the tests are described below.

\subsubsection{Planning Integration}

For the initial test, we applied the revised PPG to the elements of the Planning Integration (WBS 1.8.2) program. The purpose of the test was to determine if the PPG was a suitable prioritization technique and to identify any changes in the PPG prior to testing with other programs. We also wanted to ensure the procedures developed to apply the PPG methodology were adequate. 
The test was conducted during February 1994, and the results were briefed to the WHC Manager of Integrated Planning, who authorized us to proceed to the next steps. The results of this preliminary test are not included in this report, however.

\subsubsection{Analytical Services}

Analytical Services is a support organization to a number of major programs at Hanford. This test, conducted on May 4, 1992, brought out a number of issues and provided some lessons learned about the use of the PPG and training needed to prepare personnel to use it. The prime issue raised during this test relates to the appropriate rating for an activity which appears to be of medium or low benefit but is necessary to support high-benefit work. See Section 3.5; Lessons Learned, and Chapter 4.0, Prioritization Methodology Issues, for further information. The outcome of the benefit scoring for Analytical Services is listed in Appendix C.

\subsubsection{Facility Operations}

Facility Operations is a major program which provides safe, secure, and environmentally sound management of former defense nuclear production facilities and the disposition of nuclear fuels associated with these facilities. This test, conducted on June 10th and 21st, 1994, also brought out a number of issues and provided some lessons learned about the use of the PPG, many of which were different than the test on Analytical Services. The prime issues raised during this test were the large dollar value of some building blocks and the related skewing of the benefit to cost ratios. See Section 3.5, Lessons Learned, and Chapter 4.0, Prioritization Methodology Issues, for further information. The outcome of the benefit scoring is listed in Appendix D.

\subsection{Lessons Learned}

Lessons learned are described below:

- Level of Knowledge of Program Evaluators - To provide a fair evaluation of a program, the program evaluators must have broad knowledge of their work scope. Otherwise, the evaluation may be skewed and may place the program being evaluated at a disadvantage due to an unrealistic low score, or other programs at a disadvantage due to an unrealistic high score. An appropriate score benefits the Hanford Site mission by representing the true relationship among all work activities.

- Training - During each test, the evaluators had to be trained to use the PPG. The training began with an overview of the intent of the PPG, followed by use of the PPG to assign benefit points based on how a work scope item contributed to each mission element. As the PPG is intended to cover all the Environmental Management work scope under way at Hanford, the wording in the PPG cells does not fit every situation perfectly. As a result, program evaluators had to be trained to pick the cell which most closely represented the risk associated with not 
performing the work scope. After applying the PPG to a few work scope activities, the evaluators began to use the PPG with relative ease.

- Ease of Use - After working with the PPG for a short period of time, program personnel displayed an ability to move through the process quite rapidly. This indicates the process, once learned, is fairly easy to use.

- Time to Evaluate - Based upon the last two tests, program personnel learned to evaluate items fairly quickly. At the start, the time to evaluate an item took as long as 15 minutes, with most of this time used as training. Toward the end of the evaluation, some work scope items were evaluated as quickly as one or two minutes.

- Probabilities - In general, using the most likely outcome of funding an activity worked well. However, there were several instances where the severity of a consequence outcome skewed the manager's view of an activity. Moderators had to remind program evaluators that increased severity of outcome does not, by itself, affect probability of occurrence--it only affects magnitude of consequence.

- Moderators - To ensure that work scope within various programs is fairly evaluated, a person(s) acting as an independent moderator should be used. A moderator should have experience in the evaluation of several programs to ensure work scopes with similar attributes are being evaluated similarly from program to program. This is especially important at work scope levels to which Sitewide funding decisions are being made and less important at costaccount plan levels.

- Revised Scoring - To complete the test on the Facility Operations program, two sessions were needed. During the first period, Facility Operations personnel were learning the process by evaluating a number of building blocks. Prior to the second session, the Facility Operations personnel researched some documents to ensure their scoring was correct. This resulted in some modification of scores assigned during the first session. This illustrates an understanding of the process and an effort to assign correct scores to program activities. If all personnel have this attitude, the quality of the scoring will be excellent, and the PPG will be a very useful tool. 


\subsection{Prioritization Methodology Issues}

This chapter discusses some of the issues that were uncovered during our research into prioritization methodologies. Most of the issues require resolution if a prioritization methodology is to be implemented. Some are fairly straightforward; others are more complicated. For some we have developed work arounds which have been tested with mixed results. Any issues that are not resolved will be discussed with the PIT prior to applying the PPG.

\subsection{Compliance}

Compliance with regulations, directives, and agreements is a common objective among DOE sites. All the prioritization methodologies we examined included compliance in one form or another. Los Alamos' technique was so focused on compliance that it essentially dominated the scoring system. Even the 1992 criteria established by DOE-RL contained compliance as an objective second only to safety.

Despite the common use of compliance as an objective, we initially were not convinced that compliance was an objective in, and of, itself. To us, it seemed (at least at first) that compliance was only a means to an end, and that end was the safety of the public, workers, and environment. Thus, by this thinking, the Site wanted to ensure public safety, and one way to do so was by complying with certain regulations regarding exposures, etc. In fact, the set of objectives listed in the first draft of the 1994 Hanford Mission Plan did not include compliance as an objective. Public health, worker safety, and environmentally sound operations were specifically called out, of course, but compliance was omitted.

We also thought that if we included compliance in the PPG, we would, in a sense, be counting environmental, safety and health protection twice. And, in our first two tests, with Integrated Planning and Analytical Services, we did not include compliance.

After discussing this problem with others involved in prioritization methods at a workshop in Albuquerque, we became convinced that compliance had to be included for three reasons:

- Many activities were required by directive, regulation, or agreement; failure to fund them may have serious consequences; and the PPG should identify those consequences.

- The PPG would more likely pass the "common sense test" if compliance were included. This would increase the likelihood of its acceptance by site managers.

- The HMP was changed to reflect compliance as an objective, and we wanted to be consistent with that document.

Therefore, in the end, we added compliance as a specific objective in the PPG. 


\subsection{Management Activities}

We had some difficulty estimating the contribution management makes to the Hanford objectives. Management is a necessary function for any program activity, but it is not always clear how to determine the specific outcome associated with the management function itself. Some program analysts argued that the objectives of health and safety were directly tied to management because managers set the tone for safety in their organizations. Other than safety, however, the impact of management activities was difficult to ascertain.

Two solutions have been suggested. The first is to consider management as a non-discretionary activity which must be funded. A potential problem with this approach is that it permits program planners to "load" management building blocks with non-management activities. A close examination of the blocks could (perhaps) identify these activities, although it may require considerable effort to do so.

A potentially more accurate approach is to allocate the cost of management functions proportionally to major program activities. Thus, each of these activities would pay for its fair share of management's costs. Large activities presumably would require more management attention and would, therefore, assume a larger portion of the associated costs. This approach requires an extra step by program planners, but that step may be warranted if it helps produce a more realistic program. Note, however, that this approach could cause a portion of the management function to be unfunded, because presumably not all activities would be above the target level.

Of the two approaches, the first is simpler and easier. The second is more accurate and may result in smaller overall management costs.

\subsection{Support and Infrastructure Activities}

Support and infrastructure activities have some characteristics in common with management activities. Again, it may be difficult to determine the contribution these activities make to Site objectives. For example, if a steam plant is not built, can we accurately estimate the impact the failure to do so will have on health, safety, environmentally sound operations, public confidence, etc. We note that the problem of infrastructure activities was acknowledged in Hanford's priority guidance of 1992. Specifically, the RL Manager's guidance was that "infrastructure...should be considered by the contractor for a determination of the level of service necessary to support the top priorities."

We attempted to estimate the impact of support activities by tying them to the programs they supported. For example, with Analytical Services, planners tied specific functions of the program to the Tank Waste Remediation System (TWRS), arguing that if Analytical Services did not accurately characterize waste samples, TWRS could not adequately develop mitigation strategies--strategies which could reduce health risks, expedite cleanup, or accomplish the work in a more cost-effective manner. While Analytical Services made this argument, they did not give themselves extra points when they scored their program. 
Another approach might be to examine support and infrastructure in a class by themselves and to compare them against each other--and not against major program activities, such as Environmental Restoration. Or, we might consider some of the Site services activities as non-discretionary, and assume they are above the target level.

Perhaps best of all would be to have building blocks for each major support activity and assign to those building blocks the same score as the supported task. It is important to have some consistency in the approach used across support activities to ensure fair estimates of those activities. Support activity managers must understand that approach and must be made to feel that they are being given full credit for their program.

\subsection{Multi-Year Activities}

Prioritization methodologies do not formally allow for multi-year activities. For the most part, these activities are considered on a year-by-year basis. This approach may not make sense, however, for those activities for which funding must be continuous--such as demolition of a facility. It would not make sense to start the decontamination and decommissioning (D\&D) activities one year and fail to complete them as scheduled because of funding reallocations. The same argument applies to construction projects that cross fiscal year boundaries.

One good way to handle this situation is to consider activities which cover more than one year as a single project at the time on inception. Then, total benefit from the activity is estimated from the project as a whole--as are total costs. Benefit-cost ratios can be calculated for the entire project and can be compared to similar ratios for other activities which may cover only a single year.

Another approach is to determine total benefits and allocate them on an annual basis for comparison with other activities. In this case, it is theoretically possible to interrupt funding a multi-year project in those cases when the annual benefits cause the activity to fall below the target line.

Yet another approach is to simply consider these activities as non-discretionary after the start of the project. This seems to make the most sense and probably should be used except for unusual cases.

\subsection{Critical Path Activities}

Prioritization methodologies generally do not differentiate among activities which are, or are not, on the critical path. This does not seem appropriate, as any slip in activities on the critical path, by definition, affects those subsequent to them. This implies a way should be found to increase the priority of critical path activities.

On the other hand, it is not possible, in some cases, to say for certain what activities are or are not on the critical path. Until we do so, any argument about such activities is moot. Nevertheless, 
planners are trying to get their program plans in shape and may identify their critical path activities in the future. In this case, an argument could be made that, for the most part, managers do not have discretion about funding those activities. This seems to be yet another case for specifying nondiscretionary activities prior to budget allocation.

Note: it may be possible that using the PPG to prioritize activities could cause a reallocation of funding, based on total benefits, which could cause the critical path to shift.

\subsection{Non-Discretionary Activities}

As the previous paragraphs indicate, there is a set of activities that the program manager has little or no control about whether or not to include them in his program. These include management activities, certain support functions, multi-year activities, and those on the critical path. There are others, as well, which will clearly be funded because of their importance. This leads to the concept of "non-discretionary" activities, by which we mean the activity will automatically be included in the decrement level funding.

Our initial inclination was to allow each program to identify those non-discretionary activities and exclude them from the prioritization process. We decided not to allow this exclusion for two reasons. First of all, it seemed appropriate to examine all activities in a program in this first application of the prioritization technique. Second, we were afraid that program managers would not be willing to identify the non-discretionary activities and might front load any such list with lower-valued projects for which they wanted to ensure funding. Nevertheless, the concept is a good one, and perhaps will be tested after managers are more comfortable with the prioritization process.

\subsection{Funded Versus Not-Funded Building Blocks}

One good reason for adopting a prioritization scheme is to address the unfunded building blocks and work scope items. The Site has a long list of activities that require funding which exceeds the target funding level; that list needs to be prioritized in case funding becomes available (as it often does for many reasons). Conversely, if funding is unexpectedly reduced, work scope must be reprioritized to make reductions, as well. Presently, we carry this complete unfunded list without a good way to differentiate among various activities.

However, as discussed in the above section on non-discretionary activities, we have applied the PPG to the entire program to get a total look at the activities that comprise it. In the future, however, it may not be necessary to consider every activity, preferring instead to concentrate on those that require funding which exceeds the target funding level. 


\subsection{Building Block Size}

It appears that the size of the building block may affect the accuracy of the prioritization tool. For example, consider a program with two activities: one of $\$ 30 \mathrm{M}$ and one of $\$ 30 \mathrm{~K}$. Clearly, the former should provide considerably more benefit in terms of risk reduction, expediting cleanup, etc. However, the PPG is not accurate enough to ensure the scales remain consistent. For example, all things being equal, proportionally the $\$ 30 \mathrm{~K}$ activity may provide more than $1 / 1000$ of the benefits of the $\$ 30 \mathrm{M}$ activity. This situation may be exacerbated when the major projects in TWRS (with a total budget $>\$ 600 \mathrm{M}$ ) must be compared to activities of much smaller programs. As mentioned earlier, benefit-cost ratios may not be the best figure of merit in some cases.

One solution is to require all programs to construct their building blocks of a certain maximum size, say $\$ 10 \mathrm{M}$. This could involve considerable extra work and may cause artificialities to be introduced into a large program such as TWRS. Nevertheless, this seems a good approach, considering the problems with the alternative of trying to compare huge activities with very small ones. Incidentally, it does not seem appropriate to try to combine several small projects into a large program. It is just too difficult to estimate the risk reductions and other benefits associated with the combined activities.

\subsection{Benefit-Cost Analysis}

Ranking the benefits of various activities is just the first step in prioritization; costs must be considered, as well. One way to do so is by dividing costs by benefits to obtain a benefit-cost ratio. This ratio can, in a sense, provide a measure of the benefits obtained from each dollar invested in a given program activity. These ratios could be ordered and a decision made to fund those with the highest ratios, not fund those with the lowest, and examine very closely those in the middle.

Another technique is to plot costs versus benefits in a X-Y plane, with the costs decreasing along the vertical axis from the origin. This produces a Parieto Frontier that graphically shows those activities that have less benefit for the same cost or greater cost for the same benefit.

The cost-benefit ratios suffer from the problem discussed in the preceding paragraph, however, as small projects with low costs probably will have the greatest cost-benefit ratio.

\subsection{Summary}

This section has discussed some of the issues which should be considered when using the PPG or any other prioritization tool. Some of these issues can be addressed fairly easily; others will be tougher. The solution, of course is to realize that any prioritization methodology is only a tool; it is not a substitute for common sense. 


\subsection{Conclusions and Recommendations}

This following conclusions and recommendations were developed as a result of the research into, and evaluation of, prioritization methodologies.

\subsection{Conclusions}

- Sites in the DOE complex have realized the need for a systematic method for prioritizing among their work scope activities.

- Hanford's present system is outdated and does not satisfy our current needs.

- The PPG, as revised to reflect Hanford objectives, has the potential to assist Hanford managers in prioritizing activities.

- There are several types of activities which do not fit the PPG technique very well. Program managers and evaluators have to pay particular attention to these activities and apply good judgment in addressing them.

- The PPG is only a tool; it does not replace common sense.

\subsection{Recommendations}

- The WHC Program Integration Team should be briefed on the revised PPG and be taught how to use it.

- The Program Integration Team should apply the PPG as a first step in prioritizing FY 1995 activities.

- DOE-RL should be briefed on the tool and their blessing on its use obtained. 


\section{Appendix A}

\section{Priority Planning Grid Use Procedure}




\section{Appendix A}

\section{Priority Planning Grid Use Procedure}

\section{A.1 Purpose}

The purpose of the Priority Planning Grid (PPG) procedure is to provide a clear understanding of the application of the PPG. The PPG is to be used to assign a relative risk/benefit value for each element or activity to be funded in a program. Once all activities have been assigned a value, they will be ranked according to their relative importance. If the costs associated with funding the activities are comparable, the value per dollar will be analyzed to determine which activities provide the highest return for each dollar invested.

\section{A.2 General Procedure}

Identify the activities to be analyzed. The size of the activities is dependent on how the information from the analysis will be used.

- For the first look at a program, or when comparing among several programs, use the highest level of Work Breakdown Structure (WBS). If these activities have been artificially separated, such as during budget drills, recombine them.

- When detailed analysis is performed on an individual element to determine the priorities of each component, break it down to the next WBS level.

The benefit associated with each activity is determined from the PPG. To maintain consistency of application from program to program, an unbiased analyst will be present during the process of assigning benefit rank scores according to the following steps.

- Using Figure A.1, (which appears on page A.2) as a guide, list all the activities to be examined across the columns of a matrix and label the rows of the matrix the same as those of the modified PPG, Appendix B. 


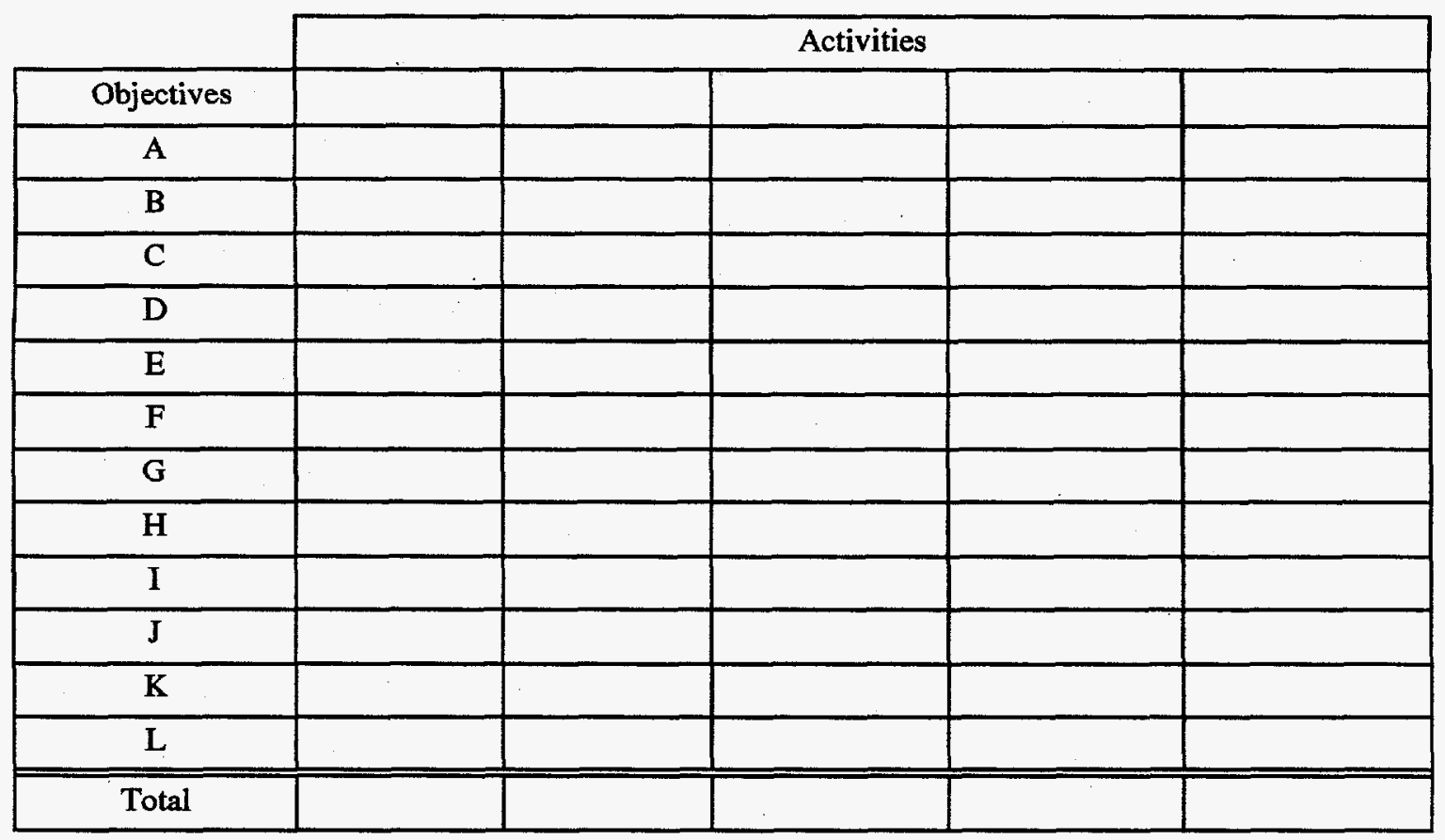

Figure A.1. Blank Form for PPG Analysis

- For each category (row), determine the benefit of the element by determining the outcome with the highest probability of occurring if the activity is funded. For that category, match the most likely outcome with the closest description found in the columns of the PPG. Look to the bottom of the PPG to determine the rank score associated with that column, and insert that number in the appropriate row of the table for the program.

- If there is a category for which the element does not provide any benefit, insert a score of "0" in the table for the program.

- Avoid ranking an element based on a low-probability, high-consequence outcome. This table is geared toward evaluating "most likely", not worst case.

Once a benefit score has been determined for each category, sum all the scores together to determine the total rank score. The total rank score represents the total benefit achieved by funding the element.

Once all activities have been analyzed, use a table similar to Figure A.2, page A.3, to list them according to their total rank scores in descending order. 


\begin{tabular}{|c|c|c|c|c|}
\hline Activity & Description & Benefit & Cost (\$M) & Benefit $/ \$$ \\
\hline & i & & ... & \\
\hline & & & & \\
\hline & & & & \\
\hline & & & & \\
\hline & & & & \\
\hline & & & & \\
\hline & & & & \\
\hline & & & & \\
\hline & & & & \\
\hline
\end{tabular}

Figure A.2. Blank Summary Form to Prioritize Program Activities

If the disparity among the funding levels of different activities, such as when working at the highest WBS level, is different by several orders of magnitude, the first-cut prioritization is now complete.

If, however, the funding levels of the activities are comparable, then plot the costs versus the total rank scores to visualize the cost-benefit relationships.

- Complete the benefit/\$ column of the table similar to Figure A.2 and list the activities in order of descending benefit $/ \$$. The resulting prioritization will provide a good first cut for budget allocation of the program.

Since all prioritization efforts will be open for discussion, the following are considerations to keep in mind when finalizing the funding priorities for a program:

- Activities with more benefits for the same investment are preferred.

- Activities with similar benefits for less cost are preferred.

- Activities with greater marginal rate of benefit/\$ invested are preferred.

- At some point, consider the amount of discretionary funding remaining; some activities may fall out. 
- Activities may not be independent; in those cases, packages of activities may be considered.

- None of the above steps substitutes for common sense and good judgment--or for other factors which are not included in the benefit equation (e.g., political, special stakeholder interests, etc.).

\section{A.3 Special Case Instructions}

This section will describe several issues that may arise when using the PPG to evaluate the program activities. (Chapter 4.0 of the main text provides further discussion of these issues.)

Compliance: By their very nature, compliance requirements are in place to ensure the health and safety of public are being met. To a lesser degree, they also cover worker and environmental health and safety. To account for the benefits gained by complying with regulations and requirements, compliance shows up in several locations.

- If an essential part of an element is in place to ensure the prevention of serious damage to the public, workers, or the environment, or ensures compliance with regulations designed to prevent serious damage to the public, workers, or the environment, the element is be ranked according to the descriptions in categories "A", "B", and "C" of the PPG, page B.1.

- When determining how to assign a benefit value in category " $\mathrm{D}$ ", Compliance with Regulations and Orders:

- Rank scores from column 4 or 5 if agreements and regulations are in place that require extensive cleanup efforts, even though analysis shows there is very little threat to the public, workers, or environment.

-. Rank scores from column 6 or 7 if agreements and regulations are in place to reduce the possibility of a future (non-safety) issue developing.

- Rank scores from column 8 if agreements and regulations are in place to ensure information is available during audits or assessments.

Management Activities: There may be difficulties in effectively assessing the worth of management activities. Management should be rolled into the broader scope of the element and evaluated based on the primary merits of the element. Or, if there is no element to be rolled into, then evaluate the function of the group and assign the same values to the management element.

Support and Infrastructure Activities: These activities, such as training, security, finance, utilities, roads, and personnel, are all essential to the effective operation of a program. However, since they may be difficult to evaluate on their own, allocate the activities to a higher-level element that they support to ensure that funding the element includes funding the support functions. 
Multi-Year Activities: Many activities span several fiscal years. When evaluating these activities, base the evaluation on the anticipated benefit of the projected end-state.

- Use the cost for the year being analyzed if costs are included in the prioritization process.

- If a multi-year activity does not make the funding cut during an out-year prioritization, compare the costs incurred by shutting down the operation and restarting at a later date with those of funding alternate activities.

Critical Path Activities: There is currently no way to incorporate the importance of critical path activities when using the PPG for prioritization. However, this is not something that can be ignored. If an activity does not make the initial cut during the prioritization process but is in the critical path of accomplishing high-priority activities, attach it to the high-priority item and reallocate the funds appropriately.

Non-Discretionary Activities: There are support activities associated with high-priority activities and there are activities that are essential to meeting the goals and objectives of the Site. In fact, many of these activities cannot really be considered "discretionary," and the first response may be to not evaluate them. However, due to their very nature, evaluation of these activities provides important information on the benefit associated with activities we really do not have any choice in funding.

Funded Versus Unfunded Building Blocks: Once the prioritization process has established a credible list of items to be funded, there will be many items that did not make the cut. Serious evaluation regarding the anticipated worth of these items and the effect of not funding them in future states should be performed. After reevaluation, the list of unfunded items needs to be clarified and prioritized in case additional money becomes available.

Activity Size: The eventual goal of the process is to evaluate the lowest level of the WBS structure to assure comparability in terms of cost. This will be a long-term goal, due to its resourceintensive nature. 


\section{Appendix B}

Modified Priority Planning Grid 
PRIORITY PLANNING GRID

SHOULD FINISII TIIE STATEMENT: IUNDING TIIS ACTIVTTY WILL...

\begin{tabular}{|c|c|c|c|c|c|c|c|c|}
\hline & 1 & 2 & 3 & 4 & 5 & 6 & 7 & 8 \\
\hline $\begin{array}{l}\text { A Ensure Public } \\
\text { Safety }\end{array}$ & $\begin{array}{l}\text { prevent site activities } \\
\text { from causing any } \\
\text { loss of public life. }\end{array}$ & $\begin{array}{l}\text { prevent sile activities } \\
\text { from causing } \\
\text { permanent physical } \\
\text { disability to the } \\
\text { public or ensures } \\
\text { compliance with } \\
\text { regulations designed } \\
10 \text { do so. }\end{array}$ & $\begin{array}{l}\text { prevent excessive } \\
\text { exposures to off-site } \\
\text { individuals or } \\
\text { ensures compliance } \\
\text { with regulations } \\
\text { designed to do so. }\end{array}$ & $\begin{array}{l}\text { prevent moderate } \\
\text { exposures and/or } \\
\text { injuries to public. }\end{array}$ & & $\begin{array}{l}\text { prevent low-level } \\
\text { exposures and/or } \\
\text { minor injury to } \\
\text { public. }\end{array}$ & $\begin{array}{l}\text { prevent reportable } \\
\text { non-process related } \\
\text { accident (e.g., traffic } \\
\text { accident). }\end{array}$ & $\begin{array}{l}\text { prevent other minor } \\
\text { incidents public may } \\
\text { be involved in. }\end{array}$ \\
\hline $\begin{array}{l}\text { B Ensure Worker } \\
\text { Safety }\end{array}$ & & $\begin{array}{l}\text { prevent site activities } \\
\text { from causing lose of } \\
\text { and for permanent } \\
\text { physical disability to } \\
\text { workers. }\end{array}$ & $\begin{array}{l}\text { prevent severe } \\
\text { exposures and/or } \\
\text { serious lost time } \\
\text { injuriea to site } \\
\text { employees or } \\
\text { ensures compliance } \\
\text { with regulations } \\
\text { designed to do so. }\end{array}$ & $\begin{array}{l}\text { prevent on-site } \\
\text { exposure close to } \\
\text { limits and/or injury } \\
\text { requiting immediate } \\
\text { altention. }\end{array}$ & & $\begin{array}{l}\text { prevent moderale } \\
\text { on-site exposure, } \\
\text { serious accident, } \\
\text { and/or minor injury. }\end{array}$ & $\begin{array}{l}\text { prevent reportable } \\
\text { onsite work } \\
\text { accident, minor } \\
\text { exposure, or skin } \\
\text { contamination. }\end{array}$ & $\begin{array}{l}\text { prevent other minor } \\
\text { incidents affecting } \\
\text { workers. }\end{array}$ \\
\hline $\begin{array}{l}\text { C Conduct } \\
\text { Environunentally } \\
\text { Sound Operations }\end{array}$ & & - & $\begin{array}{l}\text { prevent spread of } \\
\text { contamination that } \\
\text { would result in the } \\
\text { loss of public } \\
\text { resources (land } \\
\text { use/property/ } \\
\text { aquifer) or cnsures } \\
\text { compliance with } \\
\text { regulations designed } \\
\text { to do so. }\end{array}$ & $\begin{array}{l}\text { prevent excessive, } \\
\text { irreparable, and/or } \\
\text { non-containable on- } \\
\text { site ecological } \\
\text { damage requiring } \\
\text { corrective action, }\end{array}$ & $\begin{array}{l}\text { prevent moderate } \\
\text { contamination spread } \\
\text { beyond site } \\
\text { boundary at levels } \\
\text { requiring sile } \\
\text { response; or } \\
\text { moderate on-site } \\
\text { ecological damage } \\
\text { requiring remedial } \\
\text { action (stabilization). }\end{array}$ & & $\begin{array}{l}\text { prevent minor } \\
\text { contamination or } \\
\text { ecological damage } \\
\text { off or on-site } \\
\text { (repairable). }\end{array}$ & $\begin{array}{l}\text { prevent other minor } \\
\text { events from } \\
\text { negatively affecting } \\
\text { environmetut. }\end{array}$ \\
\hline $\begin{array}{l}\text { D Compliance with } \\
\text { Regulations and } \\
\text { Orders }\end{array}$ & & & & $\begin{array}{l}\text { ensure compliance } \\
\text { with regulations and } \\
\text { orders in place to } \\
\text { assure minimum } \\
\text { ES\&H levels for } \\
\text { pulic, worker, and } \\
\text { environment. }\end{array}$ & & $\begin{array}{l}\text { support regulations } \\
\text { and orders in place } \\
\text { as safeguards to } \\
\text { prevent future } \\
\text { ES\&H iseues for the } \\
\text { public, workers, or } \\
\text { the environment. }\end{array}$ & & $\begin{array}{l}\text { mpport regulations } \\
\text { and orders in place } \\
\text { for inspection and/or } \\
\text { audit purposes. }\end{array}$ \\
\hline $\begin{array}{l}\text { E Conduct Cost- } \\
\text { Effective Operations }\end{array}$ & 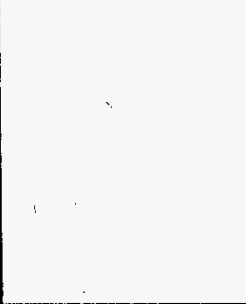 & & & $\begin{array}{l}\text { significantly } \\
\text { - increase benefits } \\
(>10 \%) \text { for current } \\
\text { investment or } \\
\text { result in } \\
\text { significant cost } \\
\text { eavings ( }>10 \%) \\
\text { with no loss of } \\
\text { benefits. }\end{array}$ & & $\begin{array}{l}\text { moderately } \\
\text { - increase benefits } \\
(5-10 \%) \text { for current } \\
\text { investment or } \\
\text { - result in moderate } \\
\text { cost sevinga (5-10\%) } \\
\text { with no loss of } \\
\text { benefits. }\end{array}$ & & $\begin{array}{l}\text { slightly } \\
\text { - increase benefits } \\
(<5 x) \text { for current } \\
\text { investment or } \\
\text { - result in tlight } \\
\text { cost savings }(<5 x) \\
\text { with no loss of } \\
\text { benefits. }\end{array}$ \\
\hline
\end{tabular}




\begin{tabular}{|c|c|c|c|c|c|c|c|c|}
\hline & 1 & 2 & 3 & 4 & 5 & 6 & 7 & 8 \\
\hline F Expedite Cleanup & & & & $\begin{array}{l}\text { - significantly } \\
\text { reduces time ( }>6 \\
\text { months) to complete } \\
\text { TPA or other major } \\
\text { milestones or } \\
\text { - enables } \\
\text { subsequent activities } \\
\text { lo start significantly } \\
\text { earlier ( }>6 \text { months) }\end{array}$ & : & $\begin{array}{l}\text { - Moderately } \\
\text { reduces time (3-6 } \\
\text { months) to complete } \\
\text { TPA or other major } \\
\text { milestones or } \\
\text { - enables } \\
\text { subsequent activities } \\
\text { to start significantly } \\
\text { earlier (3-6 months) }\end{array}$ & & $\begin{array}{l}\text { Contributes to } \\
\text { meeting TPA or } \\
\text { other major } \\
\text { milestones or } \\
\text { ( may have minor } \\
\text { (<3 months) impact } \\
\text { on schedule }\end{array}$ \\
\hline $\begin{array}{l}\text { G Develop } \\
\text { Stakeholder } \\
\text { Confidence }\end{array}$ & & & & $\begin{array}{l}\text { significantly } \\
\text { - increase } \\
\text { stakeholder } \\
\text { confidence; } \\
\text { * contribute to } \\
\text { stakeholder } \\
\text { participation in } \\
\text { Hanford decision } \\
\text { making; or } \\
\text { - demonstrate } \\
\text { Hanford commitment } \\
\text { to stakeholder } \\
\text { values. } \\
\end{array}$ & & $\begin{array}{l}\text { moderately } \\
\text { - increase } \\
\text { stakeholder } \\
\text { confidence; } \\
\text { - contribute to } \\
\text { stakeholder } \\
\text { participation in } \\
\text { Hanford decision } \\
\text { making; or } \\
\text { - demonstrate } \\
\text { Hanford conmitment } \\
\text { to stakeholder } \\
\text { values. } \\
\end{array}$ & & $\begin{array}{l}\text { slightly } \\
\text { - increase } \\
\text { stakeholder } \\
\text { confidence; } \\
\text { - contribute to } \\
\text { stakeholder } \\
\text { participation in } \\
\text { Hanford decision } \\
\text { making; or } \\
\text { - demonstrate } \\
\text { Hanford } \\
\text { commitment to } \\
\text { stakeholder values. } \\
\end{array}$ \\
\hline $\begin{array}{l}\text { II Support } \\
\text { Economic Transition } \\
\text { of Region }\end{array}$ & & & & $\begin{array}{l}\text { significantly } \\
\text { contribule to long- } \\
\text { term economic } \\
\text { goals. } \\
\end{array}$ & & $\begin{array}{l}\text { moderately } \\
\text { contribule lo long- } \\
\text { term economic } \\
\text { goals. }\end{array}$ & & $\begin{array}{l}\text { slightly contribute to } \\
\text { long-term economic } \\
\text { goals. }\end{array}$ \\
\hline $\begin{array}{l}\text { I Excellence in } \\
\text { Science, \& } \\
\text { Enginecring } \\
\text { Techrology and } \\
\text { Education }\end{array}$ & & & & & $\begin{array}{l}\text { result in innovations } \\
\text { with international } \\
\text { applicationa and/or } \\
\text { will directly support } \\
\text { S\&E education. } \\
\end{array}$ & & $\begin{array}{l}\text { result in innovations } \\
\text { with national } \\
\text { applications and/or } \\
\text { indirectly support } \\
\text { S\&E education. }\end{array}$ & \\
\hline $\begin{array}{l}\text { J RL, Contractors, } \\
\text { and SLakeliolders } \\
\text { Working as * Teain }\end{array}$ & & & & & $\begin{array}{l}\text { offer significant } \\
\text { opportunity for } \\
\text { teamwork in } \\
\text { llanford operations } \\
\text { and management. }\end{array}$ & . & $\begin{array}{l}\text { contribute to } \\
\text { teamwork in } \\
\text { Hanford operations } \\
\text { and managernent. }\end{array}$ & \\
\hline $\begin{array}{l}\text { K Transition } \\
\text { Workforce to } \\
\text { Cleanup Mission }\end{array}$ & & & & & & $\begin{array}{l}\text { aignificantly support } \\
\text { workforce training } \\
\text { and education } \\
\text { efforts. }\end{array}$ & & $\begin{array}{l}\text { moderately support } \\
\text { work force iraining } \\
\text { education efforts. }\end{array}$ \\
\hline $\begin{array}{l}\text { RELATIVE RISK } \\
\text { VALUES }\end{array}$ & 250 & 200 & 125 & 60 & 30 & 15 & 5 & 1 \\
\hline
\end{tabular}


Appendix C

Analytical Services 
Table C.1. Sorted by Benefit Points

\begin{tabular}{|c|c|c|c|}
\hline $\begin{array}{c}\text { Tasks } \\
\text { (Program Priority) }\end{array}$ & Total Benefit Points & Cost (\$) & $\begin{array}{l}\text { Benefit to Cost Ratio } \\
\text { (\$K) }\end{array}$ \\
\hline $\begin{array}{l}\text { Program Integration/HASM } \\
\text { (6) }\end{array}$ & 226 & 3,220 & 70.2 \\
\hline $\begin{array}{l}\text { Lims/Development Implementation } \\
\text { (9) }\end{array}$ & 136 & 1,700 & 80.0 \\
\hline $\begin{array}{l}325 \text { Facility Operations } \\
\text { (3) }\end{array}$ & 123 & 11,900 & 10.3 \\
\hline $\begin{array}{l}\text { 222-S Facility Operations } \\
\text { (1) }\end{array}$ & 123 & 27,500 & 4.4 \\
\hline $\begin{array}{l}\text { 222-S Facility Operations } \\
\text { (funded by TWRS) } \\
\text { (2) }\end{array}$ & 123 & $(5,000)$ & 24.6 \\
\hline $\begin{array}{l}\text { 222-S Laboratory Facility Renovations } \\
\text { (10) }\end{array}$ & 93 & 2,841 & 32.7 \\
\hline $\begin{array}{l}325 \text { Facility Renovations } \\
\text { (11) }\end{array}$ & 93 & 1,500 & 62.0 \\
\hline $\begin{array}{c}\text { 219-S Tank Upgrades (W-178) } \\
\text { (16) }\end{array}$ & 81 & 2,080 & 38.9 \\
\hline $\begin{array}{l}\text { W-087 Radioactive Liquid Waste Line Replacement } \\
\text { (15) }\end{array}$ & 81 & 9,107 & 8.9 \\
\hline $\begin{array}{l}\text { 222-S Productivity' } \\
\text { Process Improvements } \\
\text { (12) }\end{array}$ & 77 & 800 & 96.3 \\
\hline $\begin{array}{l}325 \text { Hot Cell Cleanout } \\
\text { (8) }\end{array}$ & 38 & 1,800 & 21.1 \\
\hline $\begin{array}{l}\text { Project Support Under Directive } \\
\text { (14) }\end{array}$ & 9 & 531 & 16.9 \\
\hline $\begin{array}{l}\text { Expense Support to Projects } \\
\text { (17) }\end{array}$ & 9 & 794 & 11.3 \\
\hline $\begin{array}{l}\text { WSCF Operations } \\
\text { (4) }\end{array}$ & 8 & 9,897 & .8 \\
\hline $\begin{array}{l}\text { Auxiliary Labs } \\
\text { (7) }\end{array}$ & 8 & 1,130 & 7.1 \\
\hline $\begin{array}{l}\text { Facility Analytical Equipment } \\
\text { (CENRTC) } \\
\text { (5) }\end{array}$ & 6 & 3,100 & 1.9 \\
\hline $\begin{array}{l}\text { Gpp/Small Projects } \\
\text { (13) }\end{array}$ & 5 & 1,200 & 4.2 \\
\hline Totals Analytical Laboratories Program & Grand Total & $\$ 66,197$ & \\
\hline
\end{tabular}

C. 1 
Table C.2. Sorted by Benefit to Cost Ratio

\begin{tabular}{|c|c|c|c|}
\hline $\begin{array}{c}\text { *Tasks } \\
\text { (Program Priority) }\end{array}$ & Total Benefit Points & Cost (\$) & $\begin{array}{l}\text { Benefit to Cost Ratio } \\
\quad(\$ K)\end{array}$ \\
\hline $\begin{array}{l}\text { 222-S Productivity/Process Improvements } \\
\text { (12) }\end{array}$ & 77 & 800 & 96.3 \\
\hline $\begin{array}{l}\text { Lims/Development Implementation } \\
\text { (9) }\end{array}$ & 136 & 1,700 & 80.0 \\
\hline $\begin{array}{l}\text { Program Integration/Hasm } \\
\text { (6) }\end{array}$ & 226 & 3,220 & 70.2 \\
\hline $\begin{array}{l}325 \text { Facility Renovations } \\
\text { (11) }\end{array}$ & 93 & 1,500 & 62.0 \\
\hline $\begin{array}{l}\text { 219-S Tank Upgrades (W-178) } \\
\text { (16) }\end{array}$ & 81 & 2,080 & 38.9 \\
\hline $\begin{array}{l}\text { 222-S Laboratory Facility Renovations } \\
\text { (10) }\end{array}$ & 93 & 2,841 & 32.7 \\
\hline $\begin{array}{l}\text { 222-S Facility Operations } \\
\text { (Funded by TWRS) } \\
\text { (2) }\end{array}$ & 123 & $(5,000)$ & 24.6 \\
\hline $\begin{array}{l}325 \text { Hot Cell Cleanout } \\
\text { (8) }\end{array}$ & 38 & 1,800 & 21.1 \\
\hline $\begin{array}{l}\text { Project Support Under Directive } \\
\text { (14) }\end{array}$ & 9 & 531 & 16.9 \\
\hline $\begin{array}{l}\text { Expense Support to Projects } \\
\text { (17) }\end{array}$ & 9 & 794 & 11.3 \\
\hline $\begin{array}{c}325 \text { Facility Operations } \\
\text { (3) }\end{array}$ & 123 & 11,900 & 10.3 \\
\hline $\begin{array}{l}\text { W-087 Radioactive Liquid Waste Line Replacement } \\
\text { (15) }\end{array}$ & 81 & 9,107 & 8.9 \\
\hline $\begin{array}{c}\text { Auxiliary Labs } \\
\text { (7) }\end{array}$ & 8 & 1,130 & 7.1 \\
\hline $\begin{array}{l}\text { 222-S Facility Operations } \\
\text { (1) }\end{array}$ & 123 & 27,500 & 4.4 \\
\hline $\begin{array}{l}\text { GPP/Small Projects } \\
\text { (13) }\end{array}$ & 5 & 1,200 & 4.2 \\
\hline $\begin{array}{l}\text { Facility Analytical Equipment } \\
\text { (CENRTC) } \\
(5)\end{array}$ & 6 & 3,100 & 1.9 \\
\hline $\begin{array}{l}\text { Wscf Operations } \\
\text { (4) }\end{array}$ & 8 & 9,897 & .8 \\
\hline Totals Analytical Laboratories Program & Grand Total & $\$ 66,197$ & \\
\hline
\end{tabular}


Appendix D

Facility Operations 
Table D.1. Sorted by Benefit Points

\begin{tabular}{|c|c|c|c|}
\hline Tasks & $\begin{array}{l}\text { Total } \\
\text { Benefit } \\
\text { Points }\end{array}$ & Cost (\$) & $\begin{array}{c}\text { Benefit } \\
\text { To Cost } \\
\text { Ratio }\end{array}$ \\
\hline PFP Surveillance \& Maintenance & 601 & 64,187 & 9.36 \\
\hline Pre-Stabilization Safe Standby Activities & 601 & 17,943 & 33.49 \\
\hline B Plant Operations & 591 & 33,644 & 17.57 \\
\hline Cesium Capsule Recovery Program Support & 465 & 1,234 & 376.8 \\
\hline Purex Surveillance and Maintenance & 246 & 33,104 & 7.43 \\
\hline Interim Actions & 242 & 5,100 & 47.45 \\
\hline Cesium Capsule Return & 215 & 3,000 & 71.67 \\
\hline Purex $\mathrm{UO}_{3}$ Deactivation & 131 & 16,700 & 7.84 \\
\hline PFP NEPA & 100 & 1,514 & 66.05 \\
\hline PFP Environment Compliance Act. & 92 & 2,173 & 42.34 \\
\hline Purex Environmental Compliance & 92 & 3,243 & 28.37 \\
\hline B Plant Environmental Compliance & 92 & 1,482 & 62.08 \\
\hline Facility Operations Program \& Environmental Management & 43 & 5,908 & 7.28 \\
\hline 300A Fuels Environmental Surveillance & 43 & 70 & 614.3 \\
\hline 300 Area Fuels Surveillance \& Maintenance & 38 & 4,530 & 8.59 \\
\hline PFP SAS Upgrades & 34 & 1,751 & 19.42 \\
\hline Total EM-30 & 1363 & 39,360 & 34.62 \\
\hline EM-30 With Productivity Commitment & 1363 & 35,000 & 38.94 \\
\hline Totals Facility Operations Program & 2263 & $\$ 156,223$ & \\
\hline
\end{tabular}


Table D.2. Sorted by Benefit to Cost Ratio

\begin{tabular}{|c|c|c|c|}
\hline Tasks & $\begin{array}{c}\text { Total } \\
\text { Benefit } \\
\text { Points }\end{array}$ & Cost $(\$)$ & $\begin{array}{c}\text { Benefit } \\
\text { To Cost } \\
\text { Ratio }\end{array}$ \\
\hline 300A Fuels Environmental Surveillance & 43 & 70 & 614.3 \\
\hline Cesium Capsule Recovery Program Support & 465 & 1,234 & 376.8 \\
\hline Cesium Capsule Return & 215 & 3,000 & 71.67 \\
\hline PFP NEPA & 100 & 1,514 & 66.05 \\
\hline B Plant Environmental Compliance & 92 & 1,482 & 62.08 \\
\hline Interim Actions & 242 & 5,100 & 47.45 \\
\hline PFP Environmental Compliance Act. & 92 & 2,173 & 42.34 \\
\hline EM 30 with Productivity Commitment & 1363 & 35,000 & 38.94 \\
\hline Total EM & 1363 & 39,360 & 34.62 \\
\hline Pre-Stabilization Safe Standby Activities & 601 & 17,943 & 33.49 \\
\hline Purex Environmental Compliance & 92 & 3,243 & 28.37 \\
\hline PFP SAS Upgrades & 34 & 1,751 & 19.42 \\
\hline B Plant Operations & 591 & 33,644 & 17.57 \\
\hline Totals Facility Operations Program & 2263 & $\$ 156,223$ & \\
\hline PFP Surveillance \& Maintenance & 601 & 64,187 & \\
\hline 300 Area Fuels Surveillance \& Maintenance & 38 & 4,530 & 8.59 \\
\hline Purex $\mathrm{UO}_{3}$ Deactivation & 131 & 16,700 & 7.84 \\
\hline Purex Surveillance and Maintenance & 246 & 33,104 & 7.43 \\
\hline Facility Operations Program \& Environmental Management & 43 & 5,908 & \\
\hline
\end{tabular}

D. 2 


\section{Distribution}

No. of

Copies

OFFSITE

12 DOE/Office of Scientific and Technical Information

\section{ONSITE}

3 DOE Richland Operations Office

J. D. Kautzky

J. M. Peterson

W. A. Rutherford

\section{Westinghouse Hanford Company}

B. A. Austin

D. L. Borders

J. L. Butcher

D. B. Pabst

S. M. O'Toole
No. of

Copies

15 Pacific Northwest Laboratory

W. A. Hesser (3)

M. S. Madden

N. M. Pyron

H. J. Roye (3)

W. G. Stillwell

Publishing Coordination

Technical Report Files (5) 